\title{
小児期・青年期に植え込み型除細動器治療を施行した症例の検討
}

吉田修一朗 ${ }^{1)}$, 大橋 直樹 ${ }^{1)}$, 西川 浩 ${ }^{1)}$,
久保田勤也 ${ }^{1)}$, 今井 祐喜 ${ }^{1)}$, 櫻井 - 2 ,
社会保険中京病院中京こどもハートセンター小児循環器科 ${ }^{1)}$,
心臟血管外科 ${ }^{2)}$

\section{Examination of Pediatric and Adolescent Patients Who Underwent Implantable Cardioverter Defibrillator Therapy}

\author{
Shuichiro Yoshida ${ }^{1)}$, Naoki Ohashi ${ }^{1)}$, Hiroshi Nishikawa ${ }^{1)}$, Kinya Kubota ${ }^{1)}$, Yuki Imai ${ }^{1)}$, Hajime Sakurai ${ }^{2)}$ \\ Departments of ${ }^{1)}$ Pediatric Cardiology and ${ }^{2}$ Cardiovascular Surgery, Chukyo Children Heart Center, Social Insurance Chukyo Hospital, Aichi, Japan
}

Background: In children, we need to decide the indications for implantable cardioverter defibrillator (ICD) implantation in consideration of somatic growth potential, complications, and long-term maintenance. In Japan, few studies on ICD therapy have been reported.

Objective: This study was performed to examine the indications for ICD and situations after ICD implantation.

Method: Six patients with first ICD implantation at $<18$ years old were examined. Demographic information, indications, approach, appropriate and inappropriate discharge data, additional therapy (catheter ablation and medication) and complications were recorded for all patients.

Results: The underlying pathology was idiopathic ventricular fibrillation (Vf) in two patients, and ventricular tachycardia after repaired tetralogy of Fallot, ventricular tachycardia after fulminant myocarditis, dilated cardiomyopathy, and long QT syndrome in one patient each. According to the guidelines of the Japanese Circulation Society, the criteria for ICD implantation were judged as class I in five patients and unclassified in one patient. The median age at ICD implantation was 12.9 years (range, 3.8-17.9 years). Duration of follow-up was 3.0 years (range, 0.8-4.9 years). Three patients received four appropriate discharges. One patient received four inappropriate discharges. Catheter ablation was performed in two cases, and medication for preventing arrhythmia was administered in five cases. No major complications were encountered during follow-up.

Conclusion: Indications for ICD therapy appear appropriate because most patients with class I experienced significant rates of appropriate discharge. No major complications were seen during follow-up. Even in the pediatric population, ICD implantation for class I patients is beneficial for preventing sudden cardiac death.

\section{要旨}

背景：小児に対する植え込み型除細動器 (ICD) の植え込み数は少なく, 全体の $1 \%$ 以下である. また合併症や長期に わたるフォローアップ等を考慮して ICD の適応を慎重に判断する必要がある.

目的：小児期・青年期に ICD 植え込みを行った症例を調べ, 当院に拐ける適応の妥当性, 植え込み後の状況につい て検討を行った.

方法：18 歳以下で ICD を植え込んだ 6 例について, 基礎疾患, ガイドラインにおける ICD 適応の class 分類, 植え达 み時の年齢, 植え込み方法, 植え込み後のショック作動状況, 頻拍治療としてのカテーテルアブレーション (ABL)や 薬物療法の有無, 合併症について検討した.

結果 : 6 例の基礎疾患は, 特発性心室細動 2 例, ファロー四徵症 (TOF) 術後, 拡張型心筋症, 心筋炎後, QT 延長症候 群 (LQTS) が各 1 例であった. ICD 適応は, 日本循環器学会ガイドラインを参考にclass I 5 例, 分類不能 1 例 と判断した. ICD 施行時年齢は 12.9(3.8〜 17.9)歳であり, 経静脈アプローチ 5 例, 外科的アプローチ 1 例であった.

2012 年 9 月 7 日受付

2013 年 5 月 14 日受理
別冊請求先：干 534-0021 大阪府大阪市都島区都島本通 2-13-22

大阪市立総合医療センター小児不整脈科 吉田修一朗 
ICD のフォローアップは平均 3.0 (0.8 4.9) 年, ショック回数は適切作動 3 例, 計 4 回であり, 心房頻拍による不適 切作動が 1 例, 計 4 回あった. カテーテルアブレーション $(\mathrm{ABL})$ は 6 例中 2 例で施行. 一方頻拍発作予防としての薬 物療法は 5 例で併用されていた。 フォローアップ期間中, 治療を要する合併症は認めなかった.

結語：小児期・青年期に㧍ける class I の症例では半数以上で ICD の適切作動を認め, 適応は妥当であったと判断し た.フォローアップ期間中, 治療を要する合併症は認めなかった.小児期・青年期であっても, 必要症例では, 積極 的に ICD を植え込むことにより生命予後の改善が期待できる.

はじめに

小児に対する植え込み型除細動器 (ICD)の植え込み 数は少なく, 全体の $1 \%$ 以下である. 小児に対する ICD の植え达み数が少ない理由として, デバイスの多くが 主に成人用であり，現在では，より小型化され経静脈 アプローチが可能となりつつあるものの, 依然静脈閉 塞の可能性や成長に伴って発生するリードトラブル, また，小児対応のデバイスとして利用可能な心外膜 パッチリードにも合併症が発生することなどの問題点 がある1 4)，そのため植え込みの際に小児期，青年期に 合わせたさまざまな工夫が必要となることが多い。ま た，適応となる疾患も，虚血性心疾患が主である成人 と異なり, 突然死のリスクの高い若年性の肥大型心筋 症, 拡張型心筋症, 運動誘発性多形性心室頻拍, QT 延 長症候群 (LQTS)なども多く含まれる，そのため小览に おける ICD の適応は成人とは別に考える必要があり, アメリカ心臟病学会や日本循環器学会で小児のガイド ライン 5,6 が提唱されている。

\section{目的}

小坚期・青年期に ICD 植え込みを行った症例を調べ, 当院に抢ける適応の妥当性, 植え込み後の状況につい て検討を行った。
対象・方法

当院で 18 歳以下にICD を植え込んだ 6 例(男 5 例, 女 1 例）を対象とし, 基礎疾患, ガイドラインにおける ICD 適応の class, 植え込み時の年齢, 植え込み方法, 植 え达み後のショック作動状況, 頻拍治療としてのカ テーテルアブレーション $(\mathrm{ABL})$ や薬物療法の有無, 合 併症について検討した.

\section{結 果}

6 例の基礎疾患は, 特発性心室細動(Vf) 2 例, ファロー 四徵症 $(\mathrm{TOF})$ 術後, 拡張型心筋症, 心筋炎後, LQTS (遺 伝子検査結果にて unclassified type と診断) が各 1 例で あった. ICD 適応の判断は, 自動体外式除細動器 (AED) による蘇生例が 4 例, 動悸症状あり電気生理学検査 (EPS) でVfの誘発が 1 例, 失神既往があり EPS でVf の誘発が 1 例であった. 日本循環器学会のガイドライ ンを参考とした ICD 適応はClass I 5 例, 分類不能 1 例であった. ICD 施行時の平均年齢は 12.9(3.8〜 17.9) 歳であり, 経静脈アプローチ 5 例, 外科的アプローチ 1 例であった(Table 1).

経静脈アプローチでは, 原則静脈閉塞の危険性を考 慮して,リードはより細い single coil タイプのリードを 用いたが，作動閾值が十分取れないためにdual coil を

Table 1 Profile of ICD implanted patients.

\begin{tabular}{ccccccccc}
\hline Case & Diagnosis & $\begin{array}{c}\text { ICD.age } \\
\text { (years) }\end{array}$ & $\begin{array}{c}\mathrm{BW} / \mathrm{Ht} \\
(\mathrm{kg} / \mathrm{cm})\end{array}$ & Symptom & AED & EPS & $\begin{array}{c}\text { Indication } \\
\text { (class) }\end{array}$ & ICD approach \\
\hline 1 & $\mathrm{p} / \mathrm{o}$ & 17.9 & $44 / 155$ & palpitation & & $\mathrm{Vf}$ & $\mathrm{I}$ & transvenous \\
& $\mathrm{TOF}$ & & & & & & & transvenous \\
2 & $\mathrm{Vf}$ & 17.0 & $63 / 167$ & syncope & + & $\mathrm{VT} / \mathrm{Vf}$ & $\mathrm{I}$ & $\mathrm{V}$ \\
3 & $\mathrm{~s} / \mathrm{p}$ myocarditis & 13.9 & $54 / 158$ & syncope & + & $\mathrm{VT} / \mathrm{Vf}$ & $\mathrm{I}$ & transvenous \\
4 & $\mathrm{DCM}$ & 12.5 & $37 / 140$ & syncope & + & $\mathrm{VT} / \mathrm{Vf}$ & $\mathrm{I}$ & transvenous \\
5 & $\mathrm{Vf}$ & 12.4 & $74 / 164$ & syncope & & $\mathrm{Vf}$ & un-classified & transvenous \\
6 & LQTS & 3.8 & $14 / 94$ & syncope & + & $\mathrm{Vf}$ & $\mathrm{I}$ & intrapericardial \\
\hline
\end{tabular}

ICD: implantable cardioverter defibrillator, BW: body weight, Ht: height, AED: automated external defibrillator,

EPS: electrophysiological study, ABL: ablation, AAD: anti-arrhythmic drug, p/oTOF: post-operative Tetralogy of Fallot, Vf: ventricular fibrillation, s/p: status of post, DCM: dilated cardiomyopathy, LQTS: long QT syndrome 

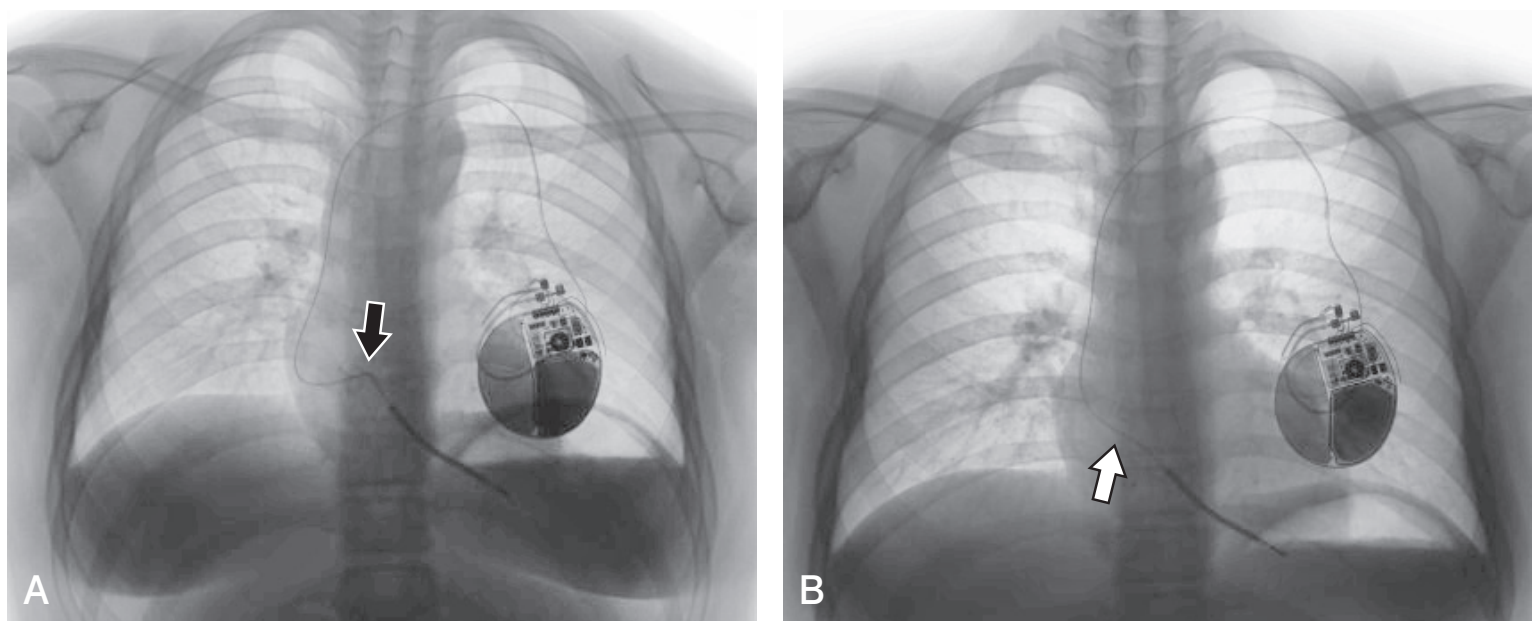

Fig.1 Patient 5.

A) After ICD implantation, leave a redundant lead loop $(\rightarrow)$ within the right atrium for further growth.

B) After a follow-up of 16 months, chest radiography showed some release of additional lead length $(\Rightarrow)$.
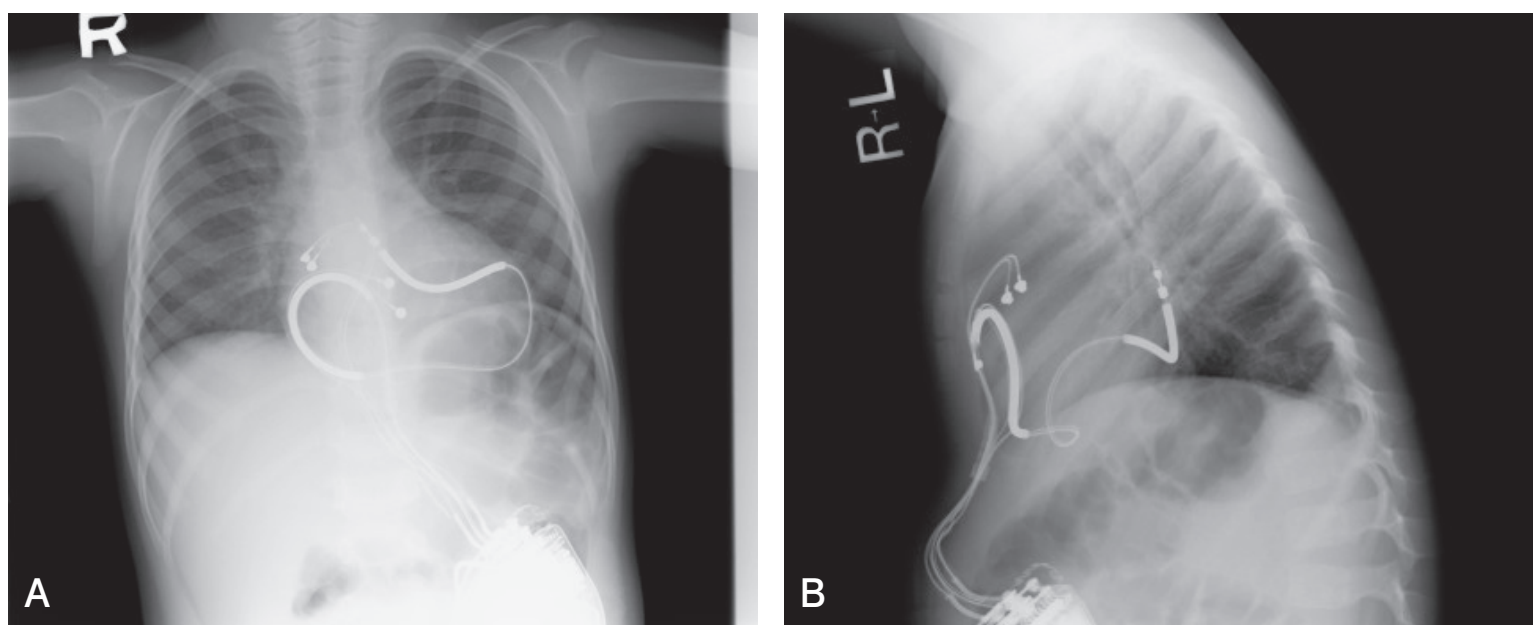

Fig.2 Patient 6.

Anteroposterior (A) and lateral (B) chest radiography after ICD implantation.

The ICD coil lead is located behind the heart.

\begin{tabular}{ccccc}
\hline ICD coil & $\begin{array}{c}\text { ABL } \\
\text { (pre/post ICD) }\end{array}$ & AAD & $\begin{array}{c}\text { Follow-up } \\
\text { (years) }\end{array}$ & shock \\
\hline dual & - & carvedilol & 3.6 & \\
dual & $+/+$ & flecainide & 2.5 & 00 \\
single & $-/+$ & propranolol & 4.9 & $\bigcirc$ \\
single & - & amiodarone & 4 & $\bigcirc$ \\
single & - & - & 2.3 & \\
dual & - & $\begin{array}{c}\text { propranolol } \\
\text { mexiletine }\end{array}$ & 0.8 & \\
\hline
\end{tabular}

VT: ventricular tachycardia, white circle $(\bigcirc)$ : appropriate shock, black circle (O) : inappropriate shock.
用いた例が 2 例あった. 15 歳以下の 3 例に対して，過 去の報告を参考に今後の成長によるリードトラブル予 防のため, 右心房や下大静脈でたわみを持たせた7). フォローアップ期間中, この 3 例で身長が平均 $16 \mathrm{~cm}$ 伸びるに従いリードのたわみがとれたが, 断線, 閾值上 昇といった合併症は認めなかった(Fig. 1). 外科的アプ ローチの場合は, 開胸し, 経静脈リードを使用して心囊 に縫着する方法8)でICDの植え込みを施行した(Fig. 2). ICD のフォローアップは平均 $3.0(0.8 \sim 4.9)$ 年であっ た. 植え达み後のショック作動状況については, 3 例, 計 4 回適切作動を認めたが, そのうち 1 例で心房頻拍 (AT) に対して計 4 回の不適切作動を認めた. 頻拍治療 として ABL は 6 例中 2 例で施行されていた。 症例 2 は, 
AED で蘇生される前に心房粗動に対して ABL が施行 されており，植え込み後も新たな $\mathrm{AT} に$ 対して不適切 作動を認めたため, 再度 $\mathrm{ABL}$ が施行された。症例 3 は ICD が複数回適切作動しており, 頻度を減らすため薬 物療法と同時にVfに関連していると考えられる心室 期外収縮 (VPC) に対して ABL を施行した。一方で症例 1 は ICD 施行後に $\mathrm{ABL}$ 予定であったが, $\mathrm{ABL}$ 施行時 にVPCの頻度が少なく $\mathrm{ABL}$ が困難であり施行しな かった. 頻拍発作予防として薬物療法は, 6 例中 5 例で 施行され, 適切作動している症例や VTを起こした症 例に対してカルベジロール，フレカイニド，プロプラ ノロール，アミオダロンが各 1 例ずつ使用されていた。 またLQTS の症例にプロプラノロール, メキシレチン が使用されていた (Table 1)。フォローアップ期間中に 治療介入を要する合併症は認めなかった。

\section{考 察}

小児に㧍ける ICD 適応基準は, 虚血性心疾患が主で ある成人と異なり，適応を成人とは別に考える必要が ある.わが国においても日本循環器学会でガイドライ ンが提唱されている. 今回の症例は, 全例 EPS を施行

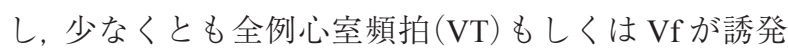
されることを確認して抢り,さらにそのうえで, 基礎 疾患の有無や年齢を考慮して, 適応の有無を評価して いる. AEDでVfが記載され蘇生された 4 例はガイド ラインに打ける二次予防の「心室細動が臨床的に確認 されている場合」小児例の「心停止からの蘇生患者で, 心肺停止が不可逆的原因による場合」に該当し class I と判断した。症例 1 は動悸症状が非常に強く, EPS で $\mathrm{VT} / \mathrm{Vf}$ が誘発されたこと, さらにTOF 術後のリスクを 考慮して, 先天性心疾患例の「先天性心疾患患者で症 状を伴う持続性心室頻拍がある場合 (ABL や外科手術 も治療選択として考慮する)」に該当し class I と判断 した，ICD 植え込み後は，VPCに対して ABLを試みる ものの, 頻度が少なく不可能で, その後も ICD の作動 はみられていないが, 最近 VT の short runを認めるよ うになりカルベジロールの内服を開始している. 症例 5 は, VPCの経過観察中に失神を認め, 失神発作時に $\mathrm{VPC}$ の 2 連発を確認し, 最終的には EPS (心室期外刺激 法 BCL400msec-S1S2 210msec S2S3190msec) でVfが誘 発されたためICDの適応と判断した。ガイドラインで は, 原因不明の失神で基礎疾患のない小览において EPS でVfが誘発された場合の記載は認めないため分 類不能と判断した. 本症例はその後も ICD 作動を認め ず，植え込みの妥当性は臨床経過で立証されていない．
EPS におけるVfは誘発条件に左右されることもあり， 臨床的意義の解釈が難しいことがある. 本症例のよう な場合, 心臓以外のより詳細な失神原因精査とともに, 植え込み型ループ心電計を含めたさらなる原因検索を 施行した後に ICD 適応を検討すべきであったかもしれ ない. またガイドラインからは class 分類の判断が困難 なことも多々あり, 医療者側と患者側との関係の中で, ケースバイケースに応じた判断をすることも必要である.

ICD を植え込むうえで, 小児領域で躊躇される因子 として, 低年齢や体格, 適応などがある. 低年齢で植え 込むことは, そこから先の電池交換や, 成長に伴うリー ド交換，またリードトラブル，経静脈アクセスによる 静脈閉塞といった合併症が懸念される.今回経静脈ア プローチでは,リードは静脈閉塞を考慮して細いもの を, また ICD 本体の容量も小さいものを選択している. そのため single coil タイプで, 心筋リード 1 本を基本原 則とした，植え込みに際して，身長が伸びることによ るリードトラブルに対応するために, 15 歳以下の 3 症 例では過去の報告をもとにリードを右心房内もしくは 下大静脈内でたわみを持たせた77).フォロー期間中に 3 症例とも身長が伸びリードのたわみは取れたが断線, 闇值上昇といったリードトラブルを認めず，一定の効 果があったと考えている，その一方でリードのたわみ が必ずしも有効ではなかったとの報告9)もあり, 本工夫 については議論のあるところである。

さらに体格の小さな症例では, 経静脈的には困難で あり外科的に植え込みを行う必要がある。 その場合 ジェネレータ本体と心外膜パッチで通電する方法もあ るが, 心外膜パッチが心筋と癒着して, 拘束型心筋症 様になり心機能低下を来したという合併症の報告もあ るため ${ }^{2,4)}$, デバイスとして, 心外膜パッチを使用する ことは躊躇される。 そのため, 今回当院では経静脈リー ドを使用して外科的に心囊に縫着する方法で ICD の植 え込みを施行した，その結果, 現在まで心機能に異常 を認めて抢らず,この方法が低年齢の ICD 植え込みに 際して, 有用と思われた8)。

今回, 経静脈アプローチは 5 例で, 3 歳の症例のみ外 科的アプローチで施行した. 3 歳で経静脈アプローチ をした報告10)もあるが, 上記合併症を考慮して当院で は 12 歳以上 $140 \mathrm{~cm}$ 以上を目安に経静脈アプローチを 行っている. しかし年齢, 体格によってどのアプロー チを選択するかは, 一定した基準もなく, 各施設によ り異なり議論があるところである。

ICD 作動状況については, 結果として植え込み後の フォローアップで3例が適切作動しており, これは低 年齢で植え込みを行わざるを得なかった ICD の妥当性 
を示唆している.一方で, 不適切作動について, 小児領 域では洞性頻脈を認識しての不適切作動や, 心内修復 術後で脚ブロックを有する症例が, 洞調律時でも wide QRS を呈することがあり，注意を要する11,12).今回，不 適切作動は 1 症例で計 4 回認めた。 スポーツ選手で高 度な運動制限を指導していたが, 運動中に $\mathrm{AT} て ゙$ て適 切作動に至った。 そのため VF 時に適切に作動し, かつ 不適切作動のないように, VT ゾーンなどの設定も随時 調整した，将来の静脈閉塞を考慮して心房リードを入 れていないため, 本症例のように心房性不整脈に対し て不適切作動する可能性はありうる。本症例は ABLに よる AT 治療により不適切作動はなくなったが, 症例 によっては合併症と不適切作動の頻度を考慮して, 症 例と体格によっては心房リードを追加することも一つ の方法と思われる。このような不適切作動を予防する ために現状の受容や病識の確立などの指導は不可欠で あるが, 精神的にまだ未熟な年齢であり非常に難しい 問題でもある. 不適切作動による精神的なストレスや 負担を回避するために, ICD を頻回チェックし設定を 工夫することも不可欠である.

ICD の前後で ABL が施行された症例 2 では, ICD 後 に AT と Vfが共存し, 特発性 Vfの背景に心筋自体の 器質的な障害が示唆された.VTの予防としてアミオダ ロンなどの薬物療法や, VTの治療として, または AT に対する ICD の不適切作動防止としての ABL は, ICD と組み合わせて行う併用療法として非常に重要であ る。一方で, 頻拍発作を抑制する目的での抗不整脈薬 の併用は, 抗不整脈薬の多くが除細動閾值を上昇させ るとされ, 注意も必要である13).

\section{結 語}

小児期・青年期に扔ける class I の症例では, 半数で ICD の適切作動を認め, 適応は妥当であったと判断し た。フォローアップ期間中に治療を要する合併症は認 めなかった. 小児期・青年期であっても必要症例では, 積極的に ICD を植え込むことにより生命予後の改善が 期待できる.

\section{【参考文献】}

1) Gasparini M, Regoni F, Galimberti P, et al: Endocardial implantation of a cardioverter defibrillator in early childhood. J Cardiovasc Electrophysiol 2005；16：1381-1383

2) Hsia TY, Bradley SM, LaPage MJ, et al: Novel minimally invasive, intrapericardial implantable cardioverter defibrillator coil system: a useful approach to arrhythmia therapy in children. Ann Thorac Surg 2009; 87: 1234-1239

3) Sherrid MV, Daubert JP: Risk and challenges of implantable cardioverter-defbrillators in young adults. Prog Cardiovasc Dis 2008; $\mathbf{5 1}: \mathbf{2 3 7 - 2 6 3}$

4) Stephenson EA, Batra AS, Knilans TK, et al: A multicenter experience with novel implantable cardioverter defibrillator configurations in the pediatric and congenital heart disease population. J Cardiovasc Electrophysiol 2006； 17: 41-46

5)奥村 謙, 相澤義房, 青沼和隆, ほか: 不整脈の非薬物治 療ガイドライン (2011年改訂版) 循環器病の診断と治療 に関するガイドライン (2010 年度合同研究班報告).ホー ムページ公開のみ

6) Epstein AE, DiMarco JP, Ellenbogen KA, et al: ACC/AHA/ HRS 2008 Guidelines for Device-Based Therapy of Cardiac Rhythm Abnormalities. A Report of the American College of Cardiology/American Heart Association Task Force on Practice Guidelines (Writing Committee to Revise the ACC/ AHA/NASPE 2002 Guideline Update for Implantation of Cardiac Pacemakers and Antiarrhythmia Devices): developed in collaboration with the American Association for Thoracic Surgery and Society of Thoracic Surgeons. Circulation 2008; 117: e350-e408

7) Gasparini M, Mantica M, Galimberti $P$, et al: Inferior vena cava loop of the implantable cardioverter defibrillator endocardial lead: a possible solution to the growth problem in pediatric implantation. Pacing Clin Electrophysiol 2000; 23: 2108-2112

8) Ichikawa Y, Iwamoto M, Yanagi S, et al: Intrapericardial and retrocardial implantation of implantable cardioverterdefbrillator lead in a child with type3 long QT syndrome. Pediatr Cardiol 2011; 32: 1048-1052

9) Antretter H, Hangler H, Colvin J, et al: Inferior vena cava loop of an endocardial pacing lead did not solve the growth problem in a child. Pacing Clin Electrophysiol 2001; 24: 1706-1708

10) Gasparini M, Regoli F, Galimberti P, et al: Endocardial implantation of a cardioverter defibrillator in early childhood. J Cardiovasc Electrophysiol 2005; 16: 1381-1383

11) Korte T, Köditz H, Niehaus M, et al: High incidence of appropriate and inappropriate ICD therapies in children and adolescents with implantable cardioverter defibrillator. Pacing Clin Electrophysiol 2004; 27 : 924-932

12) Botsch MP, Franzbach B, Opgen-Rhein B, et al: ICD therapy in children and young adults: low incidence of inappropriate shock delivery. Pacing Clin Electrophysiol 2010; 33: 734-741

13) Pacifico A, Hohnloser SH, Williams JH, et al: Prevention of implantable-defibrillator shocks by treatment with sotalol. D,L-Sotalol Implantable Cardioverter-Defbrillator Study Group. N Engl J Med 1999; 340：1855-1862 